\title{
Effect of omitting one milking weekly on milk production and quality characteristics
}

B O'Brien, D Gleeson, J Humphreys

Teagasc, Fermoy, Co. Cork, Ireland

Email: bernadette.obrien@teagasc.ie

Introduction Milking cows twice a day is a time-constraining task for dairy farmers (Clark et al., 2006). Omitting one milking weekly, particularly a week-end afternoon milking may offer an opportunity to reduce labour costs if the farm employs hired labour, or alternatively to improve lifestyle in a family operated farm situation. The objective of the current study was to determine the effect of thirteen times per week milking (13TWM) at different stages of lactation compared to normal twice per day (TAD) milking every day, in terms of milk yield, composition and quality.

Materials and methods Thirty-six spring-calving, pluriparous Holstein-Friesian cows were assigned to one of three treatments after calving (12 cows per treatment); normal TAD milking (TAD); 13TWM commencing at approximately 50 days in milk (DIM) (13TWM 50); 13TWM commencing at approximately 180 DIM (13TWM 180), balanced for calving date, cow breed, somatic cell count (SCC), lactation number and milk yield in previous lactation. In the 13TWM treatments one milking each week was eliminated from the milking routine; cows were not milked on Wednesday afternoons. Mean calving date for all cows was $20^{\text {th }}$ February. The trial extended to the end of lactation when cows were dried off at $7 \mathrm{~kg}$ milk/cow per day. Cows were allocated grass daily within a rotational grazing system and grazed to an average postgrazing sward surface height of $50 \mathrm{~mm}$. Cows received $384 \mathrm{~kg}$ concentrate during the course of the lactation. When concentrate meals were being fed, the weekly meal fed was the same for all cow groups. Individual cow milk yield was recorded daily. The milk fat, protein and lactose concentrations were determined weekly. Cow live weight and body condition score (BCS) were recorded weekly and fortnightly, respectively. Bulk milk SCC was measured weekly. All data were analysed according to a factorial design using the PROC Mixed procedure in SAS.

Results Cumulative milk yield, yields of milk solids (MS) and fat, protein and lactose concentrations were not different for the three treatments (Table 1). Cow live weight and BCS were also similar for the three treatments. Average milk SCC of the treatment groups TAD, 13TWM 50 and 13TWM 180 were $163 \times 10^{3}, 164 \times 10^{3}$ and $147 \times 10^{3}$ cells/ml, respectively. Only minor changes in SCC were observed on the day after the omitted milking. The relatively low SCC levels may be influenced by the fact that only cows with $\mathrm{SCC}<200 \times 10^{3}$ cells $/ \mathrm{ml}$ in the previous lactation and during the pre-trial period were used.

Table 1 Effect of omitting one milking weekly (13TWM) commencing at 50 and 180 days in milk compared to normal twice a day (TAD) milking on milk production characteristics

\begin{tabular}{lccccc}
\hline & TAD & 13TWM 50 & 13TWM 180 & SE & \multicolumn{2}{c}{ Significance } \\
\hline Cummulative milk yield (kg/cow) & 6128 & 6498 & 6352 & 274.6 & NS \\
Cummulative milk solids yield (kg/cow) & 477 & 502 & 481 & 20.6 & NS \\
Mean milk fat (g/100g) & 4.16 & 4.11 & 4.00 & 0.115 & NS \\
Mean milk protein $(\mathrm{g} / 100 \mathrm{~g})$ & 3.61 & 3.64 & 3.60 & 0.040 & NS \\
Live weight at end of trial $(\mathrm{kg})$ & 655 & 655 & 642 & 16.8 & NS \\
\hline \hline
\end{tabular}

Conclusion In conclusion, the data indicates that omitting milking on one consistent occasion per week does not adversely affect overall milk yield, composition or quality.

\section{References}

Clarke, D., Phyn, C.V.C., Tong, M.J., Collis, S.J. and Dalley, D.E. 2006. Journal of Dairy Science. 89, 1854 - 1862. 